\title{
Mediation and the Neocolonial Legal Order: Access to Justice and Self-Determination in the Philippines
}

\author{
EDUARDO R. C. CAPULONG*
}

Access to justice and self-determination are goals central to the export of U.S.-style mediation. Ideologically, structurally, and practically, however, U.S.-style mediation programs individualize and depoliticize conflict; centralize and homogenize law and dispute resolution; and eschew the assertion of human rights. Using community mediation in the Philippines as an example, the author argues that access to justice and self-determination in postcolonial community mediation settings require structural reform and counterhegemonic practices driven by a normative agenda that collectivizes and socializes conflict; respects and improves upon indigenous dispute resolution; and recognizes fundamental human rights.

\section{INTRODUCTION}

Is the export of U.S.-style alternative dispute resolution ("ADR") simply the propagation of technocratic, apolitical methods of resolving conflict and good governance? Or is it imperialist "soft technology" perpetuating neocolonial hegemony? On the one hand, proponents argue that U.S.-style ADR is cross-culturally adaptable, and provides greater access to justice and self-determination to parties otherwise without legal recourse. ${ }^{1}$ On the other, critics counter that the effort promotes a neoliberal agenda of capitalist

* Associate Professor of Law and Director, Mediation Clinic, University of Montana School of Law. Thanks are due to Che Aquino, Nestor Suguitan, Ruby Cabrera, Floris Inocencio, and the rest of the Paranaque and Caloocan Philippine Mediation Center staff for guiding my field research. I benefited greatly from conversations with Christine Harrington, Amy Cohen, Andrew King-Ries, Cynthia Alkon, Danya Reda, Nancy Welsh, and Bobbi McAdoo. Karen Alley deserves much credit for her excellent research and field work assistance. Rebecca Weston shared her usual keen insight on key parts of this paper; she, Elijah, and Isabella were the best companions one could hope for during a hectic travel schedule that mixed business with pleasure.

${ }^{1}$ See, e.g., Nancy D. Erbe, Appreciating Mediation's Global Role of Promoting Good Governance, 11 HARV. NEgot. L. REV. 355 (2006); Robert J. Grey, Jr., Promoting the Rule of Law by Facilitating Alternative Dispute Resolution, 16 No. 4 DISP. RESOL. MAG. 29 (2010). 
globalization and, with it, a pacifist ideology of social control. ${ }^{2}$ On the ground, scholars have observed that the spread of U.S.-style ADR produces sites for local resistance and popular justice. ${ }^{3}$ Implementing U.S.-style ADR in former Western Colonies, it turns out, reproduces a neocolonial dynamic of domination and resistance between former colonial master and subject.

In this article, I examine how this process is unfolding in the Philippines, a former U.S. colony. International rule-of-law programs-the vehicles for the export of U.S.-style mediation - have led to wide-ranging reforms in that country, among them the strengthening of the neighborhood justice system, expansion of court-annexed mediation, and enactment of the Alternative Dispute Resolution Act of 2004. Analyzing how such efforts are affecting three grassroots-level dispute-processing systems-indigenous dispute resolution, the neighborhood justice system, and court-annexed mediation-I focus on how community mediation can promote genuine access to justice and self-determination. ${ }^{4}$

This article proceeds in four parts. Drawing from representative case studies, I highlight in Part I emerging practices in the global South counterhegemonic to the fundamentals of U.S.-style mediation. In Part II, I describe the Philippine community mediation experience, in particular the ideologies, structures, and practices of indigenous dispute resolution, the neighborhood justice system, and court-annexed mediation. In Part III, I discuss access to justice and self-determination as they relate specifically to community mediation in a postcolonial context. Finally, in Part IV, using qualitative research I conducted in the country in the summer of 2010, I critique the implementation of U.S.-style mediation in the Philippines as antithetical to access to justice and self-determination, propose structural and other

${ }^{2}$ LAURA NADER, THE LIFE OF THE LAW 60-69 (2002); Laura Nader, The Globalization of Law: ADR as "Soft" Technology, 93 AM. SOC'Y INT'L L. PROC. 304 (1999).

${ }^{3}$ Raquel Aldana \& Leticia M. Saucedo, The Illusion of Transformative Conflict Resolution: Mediating Domestic Violence in Nicaragua, 55 BUFF. L. REV. 1261 (2008); Amy J. Cohen, Debating the Globalization of U.S. Mediation: Politics, Power, and Practice in Nepal, 11 HARV. NEGOT. L. REV. 295 (2006); see also Maureen Cain, Beyond Informal Justice, 9 CONTEMP. CRISES 335, 339 (1985); Christine B. Harrington \& Sally Engle Merry, Ideological Production: The Making of Community Mediation, 22 LAW \& SOC'Y REV. 709 (1988) (discussing community mediation in U.S. as ideological struggle over social control and social resistance); Anthony Wanis-St. John, Implementing ADR in Transitioning States: Lessons Learned From Practice, 5 HARV. NEG. L. REV. 339 (2000).

${ }^{4}$ For a history of community mediation in the United States, see Timothy Hedeen, Institutionalizing Community Mediation: Can Dispute Resolution "of, by, and for the People" Long Endure?, 108 PENN ST. L. REV. 265 (2003). 
practical changes, and theorize a framework for counter-hegemonic community mediation practice in the neocolonial setting. Access to justice and self-determination in neocolonial settings, I argue, requires community practices founded on a substantive normative agenda that collectivizes and socializes conflict, respects and improves upon indigenous disputeresolution, and recognizes fundamental human rights.

\section{MEDIATION AND NEOCOLONIALISM}

Whether called "law and development"5 or "legal imperialism,"6 law, as Laura Nader has argued, always has been the "handmaiden" of empire.7 Today, the renewed emphasis on the "rule of law" is political strategy, "a way to build trade and commerce" according to the Washington Consensus. ${ }^{8}$ "Law [is] deemed central abroad to govern the new commercial order," Yves Dezalay and Bryant Garth argue, "to protect against overreaching state bureaucracies, and to position countries to participate in expanding global markets in goods and services." As Rosa Ehrenreich Brooks put it, "promoting the rule of law has become a fundamentally imperialist enterprise, in which foreign administrators, backed by large armies govern societies that have been pronounced unready to take on the task of governing themselves."10 In Asia and elsewhere, the rule of law "is now deemed an article of faith for good governance."11

${ }^{5}$ See, e.g., Kevin Davis \& Michael J. Trebilcock, The Relationship Between Law \& Dev't: Optimists Versus Skeptics, 56 AM. J. CoMP. L. 895 (2008); Kerry Rittich, Who's Afraid of the Critique of Adjudication?: Tracing the Discourse of Law in Development, 22 CARDozo L. REV. 929, 940 (2001); Francis G. Snyder, The Failure of "Law \& Development," 1982 WIS. L. REv. 373; David M. Trubek, Toward A Social Theory of Law: An Essay on the Study of Law and Development, 82 YALE L. J. 1 (1972).

${ }^{6}$ See, e.g., Rosa Ehrenreich Brooks, The New Imperialism: Violence, Norms, and the "Rule of Law," 101 MicH. L. REV. 2275 (2003).

${ }^{7}$ Nader, supra note 2, at 304.

8 Yves DeZalay \& Bryant G. Garth, Asian Legal ReVivals 6 (2010).

${ }^{9}$ Id. at 173.

${ }^{10}$ Brooks, supra note 6, at 2280. Department of Justice Undersecretary Jose Salazar seemed to confirm this when he declared in his introductory remarks at a 2010 ADR conference in Manila that by providing a "juridical foundation for ADR," the 2004 ADR Act would bolster the "transborder predictability of loss . . . Part of the job is to attract direct investment." Author's notes, The State of ADR in the Philippines: The OADR National Consultative Conference (July 28, 2010), Manila, Philippines. Indeed, by 
Promoting the rule of law also has come to include what Nader calls the "globalization of informal law"-or ADR. ${ }^{12}$ International rule-of-law initiatives began including $\mathrm{ADR}$, and mediation specifically, as a programmatic component in the mid-1990s. ${ }^{13}$ Led by the U.S. Agency for International Development (USAID), the World Bank, and the American Bar Association (ABA), U.S.-style, primarily facilitative, mediation ${ }^{14}$ has since become prevalent the world over-from Central and South America ${ }^{15}$ and

marshaling state resources in pursuit of that goal, the purpose of that law seems to be the transfer of the costs of private dispute resolution to the state.

11 DeZalay \& GARTH, supra note 8 , at 2; see also James Thuo Gathii, Representations of Africa in Good Governance Discourse: Policing and Containing Dissidence to Neoliberalism, 1998-99 THIRD WORLD LEGAL STUDIES 65 (arguing that good govemance, neo-liberalism, and structural adjustment are interchangeable ways of imposing Bretton Woods agenda/Washington consensus).

12 Nader, supra note 2, at 304. For a survey of international ADR programs, see also Mauro Cappelletti, Alternative Dispute Resolution Processes within the Framework of the World-Wide Access-to Justice Movement, 56 MOD. L. REV. 282 (1993).

13 See Jean R. Sternlight, Is Alternative Dispute Resolution Consistent with the Rule of Law? Lessons from Abroad, 56 DEPAUL L. REV. 569, 572 (2007) (Since 1990, "the World Bank alone has sponsored 330 rule of law projects totaling $\$ 2.9$ billion.") (quoting David M. Trubek, The "Rule of Law" in Development Assistance: Past, Present, and Future, in THE NEW LAW AND ECONOMIC DEVELOPMENT: A CRITICAL APPRAISAL 74, 74 (2006); see also Brooks, supra note 6.

14 Here, I use the term U.S.- or Western-style mediation to refer to the facilitative and transformative methods, a process characterized by an intervention of a third-party neutral, "helping people make choices and holding them accountable; helping people identify and control their feelings; encouraging personal growth (i.e., self-esteem and empathy) ... and promoting peaceful resolution of conflict." Aldana \& Saucedo, supra note 3, at 1267 (internal citation omitted). The export of Western ADR has not been characterized by evaluative practices. See, e.g., Nancy Erbe, The Global Popularity and Promise of Facilitative ADR, 18 TEMP. INT'L \& COMP. L.J. 343 (2004); Kenneth H. Fox, Unanswered Questions Future Opportunities: Reflections on an International Conversation About the Globalization of ADR, 27 HAMLINE J. PUB L. \& POL'Y 297, 305 (2006) (primary export is facilitative or problem-solving model); Leonard Riskin, Decisionmaking in Mediation: The New Old Grid and the New New Grid System, 79 Notre DAME L. REV. 1 (2003).

15 Erbe, supra note 1, at 371-72 (discussing "growing popularity" of facilitative mediation in international arena). But see id. at 391 (mentioning transformative mediation); Aldana \& Saucedo, supra note 3, at 1272 (discussing transformative mediation in Nicaragua). See generally Grey, supra note 1 (discussing programs in Mexico, Liberia, and Bulgaria); Mariana Hernandez Crespo, A Systemic Perspective of ADR in Latin America: Enhancing the Shadow of the Law Through Citizen Participation, 10 CARdozo J. CONFLICT RESOL. 91 (2008); Jose Alberto Ramirez Leon, Why Further 
the Caribbean, ${ }^{16}$ to Central and Eastern Europe, ${ }^{17}$ Africa, ${ }^{18}$ and Asia. ${ }^{19}$ In fact, the adoption of ADR methods is a condition of Western foreign aid to the global South. ${ }^{20}$

Notwithstanding the tension between these two concepts-mediation is, after all, private and informal while law is public and formal-proponents argue that mediation and the rule of law are compatible insofar as mediation provides greater access to justice and self-determination. ${ }^{21}$ Specifically, proponents argue that mediation-that is, the informal, confidential intervention of a third-party "neutral"--is more efficient and effective than courts, particularly in countries where the judiciary is corrupt, is less costly, is more responsive to the poor and disenfranchised, is more culturally appropriate, promotes greater social harmony, and helps the judiciary provide a better quality of justice by reducing caseloads and therefore enhancing courts' work. 22

Development of ADR in Latin America Makes Sense: The Venezuelan Model, $2005 \mathrm{~J}$. DISP. RESOL. 399; Thomas J. Moyer \& Emily Stewart Haynes, Mediation as a Catalyst for Judicial Reform in Latin America, 18 OHIO ST. J. ON DISP. RESOL. 619 (2003); Sternlight, supra note 13.

16 See, e.g., Richard C. Reuben, ADR and the Rule of Law Making the Connection, 16 DisP. RESOL. MAG. 4 (2010) (mentioning India and the Dominican Republic).

${ }^{17}$ Cynthia Alkon, The Cookie Cutter Syndrome: Legal Reform Assistance Under Post-Communist Democratization Programs, 2002 J. DISP. ReSOL. 327; Steven Austermiller, Mediation in Bosnia and Herzegovina: A Second Application, 9 YALE HUM. RTS. \& DEV. L.J. 132 (2006); Emily Stewart Haynes, Mediation As An Alternative to Emerging Postsocialist Legal Institutions in Central and Eastern Europe, 15 OHIO ST. J. ON DisP. RESOL. 257 (1999).

18 Nader, supra note 2, at 60-69; Anthony P. Greco, $A D R$ and a Smile: Neocolonialism \& the West's Newest Export in Africa, 10 PEPP. DiSP. RESOL. L.J. 649 (2010).

${ }^{19}$ See, e.g., Cohen, supra note 3 (Nepal); James E. McGuire, Rule of Law and ADR in China: Observations on Recent Developments, 16 No. 4 DISP. RESOL. MAG. 20 (2010) (China).

${ }^{20}$ Laura Nader \& Elisabetta Grande, Current Illusions \& Delusions about Conflict Management-In Africa \& Elsewhere, 27 LAW \& SOC. INQUIRY. 573, 591 (2002).

${ }^{21}$ See, e.g., Austermiller, supra note 17, at 140-43 (2006); Leon, supra note 15; Reuben, supra note 16, at 4-5 (discussing "thin" and "thick" descriptions of "rule of law."). Note, however, that the argument does not necessarily respond to the compatibility of mediation with the rule of law as such. See Alkon, supra note 17 (arguing for inclusion of ADR in rule of law efforts and against a generalized approach to international development assistance).

22 See, e.g., Leon, supra note 15 (arguing, inter alia, that ADR can support and complement court reform, increase access to justice and facilitate other social change); 
Critics, however, denounce the propagation of U.S.-style mediation as promoting neocolonial hegemony - the antithesis of justice and selfdetermination. Nader has been the staunchest and most consistent of these critics, developing in her body of work that "in colonial, national and international settings, harmony law models (consensus-producing models) have been powerful tools of pacification and control." 23 "Harmony law models are often coercive mechanisms of control," she argues, "providing a style of dispute resolution that may move down the slippery slope of lawlessness." 24 Indeed, the observable successes of mediation-how it involves parties in an "ongoing process," consensus-building, and relationship-building 25 -are fully in line with her (and other critics') contention that mediation expands the ambit of state power, defeats democratic decisionmaking, and preserves rather than transforms unequal relationships. ${ }^{26}$ As Nader puts it, "Western Christianity spread the harmony legal model in a manner that resembles the modern ADR movement. Both emphasized compromise and consensus as a preferred way of decisionmaking-peace over justice being a mandatory result."27

On the ground, the reality is more complex. The import of U.S.-style ADR "create[s] a space for political action," 28 one characterized by the

Sternlight, supra note 13, at 573; Anthony Wanis-St. John, Implementing ADR in Transitioning States: Lessons Learned From Practice, 5 HARV. NEGOT. L. REV. 339, 339 (2000) (using terms "transitioning states," "developing world," and "emerging democracies" to describe countries undergoing judicial/ADR reform). In the Philippine context, see Special Rules of Court on Alternative Dispute Resolution, A.M. No. 07-1108-SC, Rule 2.1 (Sept. 1, 2009) ("policy of the State to actively promote the use of various modes of $\mathrm{ADR}$ and to respect party autonomy or the freedom of the parties to make their own arrangements in the resolution of disputes with the greatest cooperation of and the least intervention from the courts ... as an important means to achieve speedy and efficient resolution of disputes, impartial justice...."); Alternative Dispute Resolution Act of 2004, Republic Act No. 9285; Operations Manual for First and Second Level Courts at 4 (establishment of Philippine Mediation Centers "contribute to ... ensure speedy access to justice.").

23 Nader, supra note 2, at 305.

24 Id. at 308.

25 Erbe, supra note 1, at 375-77.

26 Richard L. Abel, 2 THE POLITICS OF INFORMAL JustiCE, 1, 1 (1982); see generally, CHRISTINE B. HARRINGTON, SHADOW JUSTICE (1985).

${ }^{27}$ Nader \& Grande, supra note 20, at 578-79.

${ }^{28}$ Cain, supra note 3, at 339 (citing Mathiesen and de Sousa Santos); see also Ugo Mattei, A Theory of Imperial Law: A Study of U.S. Hegemony and the Latin Resistance, 10 IND. J. GLOBAL LEGAL STUD. 383, 389 (2003) ("Legal transplants cannot be seen as 
struggle between the effort to expand state control by non-state means-as Richard Abel has argued 29 _and the:

effort[] by nonstate groups to capture this space for themselves, to counter the expansion of state law with forms of justice based on sources of authority outside the state. The contest waxes and wanes through processes of reform, counterreform, bureaucratization, decentralization, informalism, refusal to keep records, refusal to participate, and user preference for state law. ${ }^{30}$

The contest is, in other words, between indigenization and counterhegemonic practice. From above, the neocolonially supported state attempts to expand control through rule-of-law programs, whose relative success comes "from the[ir] ability to link to local strategies that suit locally embedded actors" 31 - i.e., indigenization. The process is no different from the imperial policy of indigenizing foreign military occupation, for example the "Iraqification" and "Vietnamization" policies in those two wars. ${ }^{32}$ U.S.style ADR must be similarly indigenized, proponents argue, a process of adaptation particularly well-suited in countries with rich traditions of indigenous dispute resolution. Comparing the Rwandan Gacaca grassroots courts, which were created to deal with the 1994 genocide in that country, and the Arbitration Center of the World Intellectual Property Organization, which provides mediation and other services to resolve international commercial disputes involving intellectual property, for example, Carlos Osi calls for an indigenized Western ADR approach to intellectual property rights issues. ${ }^{33}$ The challenge, Osi argues, is to fuse the indigenous with the

happening as the result of the choice of one mind that freely or coactively receives the produced model. Both in the phase of production and in the phase of reception, legal transplants are a lively dialectic between consent and dissent, between hegemonic and counter-hegemonic forces, between mainstream and critical approaches.").

29 Abel, supra note 26.

${ }^{30}$ Sally Engle Merry, Sorting Out Popular Justice, in SALLY ENGLE MERRY \& NEAL Milner, THE Possibility of Popular Justice: A Case STUdy of COMMUNITY MEDIATION IN THE UNITED STATES 61 (1993).

31 DEZALAY \& GARTH, supra note 8, at 170.

${ }^{32}$ See, e.g., Fareed Zakariya, Iraqification: Losing Strategy, WASH. Post, Nov. 4, 2003, at A25; Robert H. Johnson, Vietnamization: Can It Work?, 48 FOREIGN AFF. 629 (1970).

${ }^{33}$ Carlo Osi, Understanding Indigenous Dispute Resolution Processes and Western Alternative Dispute Resolution, 10 CARDOZO J. CONFLICT RESOL. 163, 207-10 (2008). 
Western. ${ }^{34}$ Anthony Greco makes a similar claim vis-à-vis Ugandan Local Council Courts. ${ }^{35}$ Tracing their origin to the Resistance Council Courts that emerged after the dictatorships of Idi Amin and Milton Obote, Greco argues that a small claims procedure in these courts would "provide a reliable and efficient rule of law without the neocolonial imposition of a foreign concept or transplant." 36 In this context, "[m]ediation, properly used as a synthesizing tool, has the potential to bridge the gap between the kind of law needed to operate in a global marketplace and the type of grass roots justice that works on the ground." 37

From below, the resistance to the expansion of state control occurs through an emerging set of counter-hegemonic practices. Rejecting state cooptation of indigenous practices, for example, Penal Reform International, an organization that has studied informal and traditional justice systems in Sub-Saharan Africa, India, and Bangladesh, argues that, to ensure access to justice, indigenous systems should, among other things, not be incorporated in the formal state judicial system, remain entirely voluntary, and issue decisions that are nonbinding. ${ }^{38}$ Penal Reform International also argues that the state should not interfere with the appointment of informal arbitrators within a community, and that such arbitrators' jurisdiction not be heavily restricted (but that physically coercive measures be prohibited). ${ }^{39}$

Extending Sally Engle Merry's and Christine Harrington's work beyond the ideological dimensions of community mediation in the United States, and refocusing the debate from methods and forms to practices and effects, Amy Cohen has found that Nepalese mediators actively use mediation as a site for grassroots political struggle..$^{40}$ In Nepal, Cohen found community mediation practices that were public, rights-based, coercive, and activist in orientation. ${ }^{41}$ Nepalese mediation practice specifically targeted sexism,

This, of course, is an ironic prescription given that U.S. community mediation was modeled after the post-colonial African community moot. See Cain, supra note 3, at 337.

34 Osi, supra note 33, at 210 .

35 Greco, supra note 18.

36 Id. at 676.

${ }^{37} \mathrm{Id}$.

38 Penal Reform International, ACCESS to JUSTICE IN SUB-SAHARAN AFRICA: THE ROLE OF TRADITIONAL AND INFORMAL JUSTICE SYSTEMS (2001).

${ }^{39}$ Id.

40 Cohen, supra note 3, at 298.

41 Id. at 297. 
promoted human rights and democracy, and advocated against state torture. ${ }^{\mathbf{4 2}}$ There is space, Cohen argues, for "an explicitly interventionist" mediation model "in which procedural design flows from the social, political, and cultural goals a dispute resolution project aims to achieve."43

Echoing the Nepalese model, Raquel Aldana and Leticia Saucedo call for an "advocacy or activist model" of mediation supported politically and organizationally by community-based organizations. ${ }^{44}$ Studying transformative mediation of domestic violence cases in Nicaragua, they, like Cohen, endorse a public, rights-based, coercive process in which the mediator, as "participant observer," "link[s] seemingly individual problems with the broader political and social context." 45 Their goal: not simply the resolution of individual cases but the eradication of domestic violence. ${ }^{46}$

Thus, scholars who have studied the transplant of U.S.-style mediation in various postcolonial settings have argued for both top-down prescriptions and bottom-up resistance to U.S.-style mediation along three axes: program ideology and design, mediator role and practice, and external political and organizational support for disputing parties. Each of these three axes is a site for political struggle. Top-down, the neocolonial agenda is manifested in a purportedly apolitical, neutral approach that seeks to "indigenize" U.S.-style mediation, and centralize law and legal processes. Bottom-up, counterhegemonic practices socially contextualize and politicize conflict, and articulate substantive normative agendas: instead of promoting the centralization of law and legal processes, they promote a plural juridical field, allowing for extra-legal outcomes. Instead of discounting legal rights, such practices infuse various processes with them. And instead of focusing only on individual rights and remedies, they collectivize conflict by linking individual claims with broader social issues and recognizing the stake and role of third-party advocacy organizations in the process.

With these practices in mind, I turn to the Philippine community mediation experience.

42 Id.

43 Id. at 337.

44 Aldana \& Saucedo supra note 3; see also Donald T. Weckstein, In Praise of Party Empowerment-And of Mediator Activism, 33 WilliaMETTE L. REV. 501 (1997).

45 Aldana \& Saucedo, supra note 3, at 1328.

46 Id. at 1329. 


\section{COMMUNITY MEDIATION IN THE PHILIPPINES}

The propagation of U.S.-style ADR in the Philippines may be seen as part of what Dezalay and Garth have called a "legal revival" in Asia, a program reasserting the "colonial imprint of law." 47 One can see the phenomenon as mirroring, in fact, the U.S. experience in the mid-1970s of extending legal empowerment strategies through the "rights revolution" and public interest law, and, later, non-adjudicative processes. 48

In the Philippines, the field of mediation may be categorized into five areas: indigenous dispute resolution, the neighborhood justice system, courtannexed mediation, administrative mediation, ${ }^{49}$ and private mediation. My focus here is on the first three systems, their relationships to each other, and the recent, Western-sponsored, reforms that have affected them. For most Filipinos needing third-party or state intervention in their disputes, these three systems govern.

\section{A. Indigenous Dispute Resolution}

Despite centuries of colonial oppression, indigenous dispute resolution ("IDR") remains a vibrant part of Filipino life. ${ }^{50}$ Filipinos engage in a diversity of practices:

${ }^{47}$ DeZALAY \& GaRTH, supra note 8, at 2.

48 See id. at $227-34$.

49 See Exec. Order No. 523 (instituting use of ADR, including mediation, in "resolution of all disputes before all administrative bodies in the Executive Department"); Office for ADR Holds National Consultative Conference, THE PHILIPPINE ADR REv. Aug. 2010, at 1, 6; see also Elmer Mercado, 2010 ADR conference, supra note 10.

${ }^{50}$ For a description of indigenous peoples, see Osi, supra note 33, at 169-75 (citing five U.N. criteria for defining term "indigenous": (1) self-identification; (2) historical continuity with preinvasion or precolonial societies; (3) nondominance; (4) ancestral territories; and (5) ethnic identity); see also Maivan Clech Lam, Indigenous Peoples' Right to Self-Determination \& Territoriality, in HUMAN RIGHTS IN THE WORLD COMMUNITY 149 (RICHARD PieRre ClaUde \& BURNS H. Weston, eds., 2006):

Indigenous communities, peoples and nations are those which, having a historical continuity with pre-invasion and pre-colonial societies that developed on their territories, consider themselves distinct from other sectors of the societies now prevailing in those territories, or parts of them. They form at present non-dominant sectors of society and are determined to preserve, develop and transmit to future generations their ancestral territories, and their ethnic identity, as the basis of their 
[t]he process is called: Tongtong among the Kakanaey and Bago peoples of Bakun; Tigian among the Alangans and Hirayas of Mindoro Occidental; Mame'epet among the Tagbanuas of Coron in Palawan; Husay among the Higaonons and Talaaandigs of Misamis Oriental and Bukidnon, Kukuman among the Tinananon Manobo of Arakan Valley; Iskukom among the T'bolis of Lake Sebu; Tiwayan among the Tedurays of Maguindanao; and Gukom among the Subanons of Zamboanga. There are also many existing indigenous justice systems that have no formal or common names but are still very much in place and in use. ${ }^{51}$

The variety and informality of these practices make generalization of IDR methodology difficult. But there are similarities among them. For example, as compared to the U.S. facilitative approach in which a third-party stranger plays the role of facilitator, in IDR authoritative elders are usually the overseer. ${ }^{52} \mathrm{IDR}$ is less dispute-resolution and more consultation process, the elders less facilitator than arbiter. ${ }^{53}$ Mediations are often book-ended by ritual, which may be spiritual, superstitious, or festive. ${ }^{54}$ There is no fixed venue, though they are often held in the elder's house. ${ }^{55}$ Frequently public or open to the community, no distinction is made between civil and criminal

continued existence as peoples, in accordance with their own cultural patterns, social institutions and legal systems.

(citing first UN study of indigenous peoples, The Study of the Problem of Discrimination Against Indigenous Populations (New York: United Nations, 1987), 5: I 379, UN Doc. E/CN.4/Sub.2/1986/7/Add.4).

51 Maria Roda L. Cisnero, Rediscovering Olden Pathways \& Vanishing Trails to Justice \& Peace: Indigenous Modes of Dispute Resolution \& Indigenous Justice Systems, in A SOURCEBOOK ON ALTERNATIVES TO FORMAL DISPUTE RESOlUTION MECHANISMS 91 (2008); see generally id. 91-128; see also Susan Aro, Philippines: 'Tongtongan,' An Indigenous Conflict Resolution, available at http://indigenouspeoplesissues.com/index.php?option=com_content\&view=article\&id=1 .0601 :philippines-tongtongan-an-indigenous-conflict-resolution \&catid $=62$ : southeast-asiaindigenous-peoples\&Itemid=84; Marly Anne Bacaron, Indigenous Conflict Resolution Mechanisms in Mindanao: Is Their Institutionalization the Answer?, 3 ASIAN J. PUB. AfF. 49, 49 (2010); Ofelia Durante, Cultivating Wisdom, Harvesting Peace, 19 KASAMA 3 (July-Aug.-Sept. 2005), available at http://cpcabrisbane.org/Kasama/2005/V19n3/OfeliaDurante.htm.

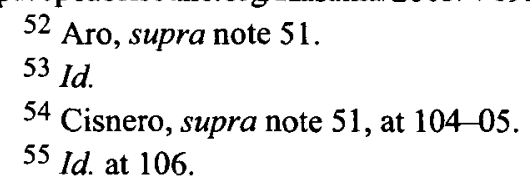


cases. ${ }^{56}$ Nor is there opportunity for appeal. ${ }^{57}$ And instead of focusing on individualized redress, IDR sees community peace or harmony as its primary goal. ${ }^{58}$ IDR processes include:

traditional teachings, respect, relationships, interconnectedness, spirituality, prayers, storytelling, "saving face," recounting of facts, and emotions ... [it is] characterized by flexibility, utilization of cyclical time, qualitative measurement of success and people-orientation. The person in the middle of the process is not just persuasive, but exemplifies the virtues of teacher and planner, given his "reputation for wisdom and knowledge of traditional lore." 59

Like their state counterparts, IDR systems "are intimately intertwined with[] varied norms and procedures that generally include the jurisdictional or justice-related functions of [] indigenous communities." 60

But like any indigenous system in a neocolonial yoke, IDR processes "are, in most cases, not properly recognized, barely understood, and hardly respected."61 "Worse," Maria Roda Cisnero writes, "most of the efforts concerning IDR [methods] are focused on integration and assimilation into, if not an interface with, the formal justice system. Codification and formalization usually become the primary recommendations." 62

56 Id. at 108 .

${ }^{57} \mathrm{Id}$. at 106,108 .

58 Id. at 107; see also Osi, supra note 33, at 194 ("Group consensus is the goal to be achieved, as well as the maintenance of good relations with other community members, solidarity and reciprocal obligations....").

59 Osi, supra note 33, at 194 (internal citations omitted).

${ }^{60}$ Cisnero, supra note 51 , at 94 . It is important to note here, however, that those indigenous norms and procedures are, themselves, often colonial creations. "One of the major insights garnered by work on law in colonial situations is that the customary law implemented in 'native courts' was not a relic of a timeless precolonial past but instead an historical construct of the colonial period. Several careful historical and anthropological studies demonstrate that the so-called 'customary law' of the colonial period was forged in particular historical struggles between the colonial power and colonized groups." Sally Engle Merry, Anthropology, Law, \& Transnational Processes, 21 ANNU. REV. ANTHROPOLOGY 357, 364 (1992).

61 Cisnero, supra note 51 , at 93.

62 Id. at 62 . 
Thus, notwithstanding constitutional language to the contrary, ${ }^{63}$ Filipino indigenous dispute resolution is tolerated only insofar as it does not collide with state interests. ${ }^{64}$ The concept of "interface," writes Cisnero, "comes from the framework that mainly "focuses on the official legal and judicial system, conceived as a unified system, and left out of this consideration is the multiplicity of unofficial legal orderings and indigenous dispute resolution mechanisms and justice systems that had long co-existed with the official systems many dating back to the pre-conquest period."'65

\section{B. The Neighborhood Justice System}

In the Philippines, the integration and assimilation of indigenous dispute resolution into the formal legal structure crystallized in the creation of the "Katarungang Pambarangay" (KP)—or neighborhood or village justicesystem. This integration and assimilation has been so successful, in fact, that it can be difficult to tell whether a dispute is being governed exclusively by an indigenous process, exclusively by the KP process, or both simultaneously. 66

Perversely, a dictator created these popular tribunals: long-time U.S. client Ferdinand Marcos, who decreed, literally, the establishment of the neighborhood justice system by executive order. ${ }^{67}$ In 1972, Marcos declared martial law to impose "law and order" on the powerful social movements

${ }^{63}$ Const. (1987), art. XIV, $\S 17$ (Phil.) ("[T]he State shall recognize, respect, and protect the rights of indigenous cultural communities to preserve and develop their cultures, traditions, and institutions.").

${ }^{64}$ See Cisnero, supra note 51, at 99 (citing Owen J. Lynch Jr.; The Philippine Indigenous Law Collection: An Introduction and Preliminary Biography, 58 PHIL. L. J. 457,459 (1983)) (stating that these laws and traditions "were suppressed if they interfered with the aspirations of soldiers, priests, entrepreneurs and government officials").

${ }^{65} \mathrm{Id}$. at $97 \mathrm{n} .13$ (internal citation omitted).

${ }^{66}$ Rachel S. Aquino, Five Municipal Case Studies on the Philippine Barangay (Village) Mediation System, at 1, 12, available at www. Ausdispute.edu/au/ampf/2008/papers/28-Rachel\%20S.AQUINO.pdf.

${ }^{67}$ Ferdinand Marcos, Presidential Decree No. 1508 (1978), available at http://philippinelaw.info/statutes/pd1508-katarungang-pambarangay-law.html. As Sally Engle Merry and Neal Milner have observed, "[p]opular-justice tribunals can be used by national political leaders to reshape society and to reeducate the populace." MERRY \& MILNER, supra note 30 , at 8 . 
that challenged his rule. ${ }^{68}$ The KP system was an integral part of his program of centralizing the state, consolidating dictatorial rule, and silencing opposition in the years to follow.

The stated purposes of the KP system were to decongest courts and amicably settle disputes. ${ }^{69}$ Then Philippine Chief Justice Fred Ruiz Castro's rhetoric paralleled those of U.S. Supreme Court Chief Justice Warren Burger's in the same period: the "overuse, misuse, and abuse of the courts." For parties in dispute, both argued, courts should be the last, not first, resort. ${ }^{71}$ But the real agenda was social control. As KP architects Cecilio Pe and Alfredo Tadiar put it, the system was created "in the total context of creating order in society." " "[J]ustice delayed is most certainly justice denied. And when the people's thirst for justice is not quenched, each man [sic] will seek to become a law unto himself and the country will once more revert to the anarchic situation which provided the justification for the imposition of martial rule."73

As we now know, Marcos himself instigated that "anarchic situation." He was behind the 1971 Plaza Miranda bombing that killed nine and injured ninety-five of his political opponents, for example, as well as numerous other atrocities that preceded (and became commonplace during) his dictatorship. ${ }^{74}$ Hence, like his counterpart and friend Richard Nixon's "law and order"

68 See generally RAYMOND BONNER, WALTZING WITH A DICTATOR (1987); Eduardo R.C. Capulong, The People Power Revolution of the Philippines, 1986, ENCYCLOPEDIA of ACTIVISM AND SOCIAL JUSTICE 1116-18 (Russell Sage ed., 2007); DicTATORSHIP \& Revolution: Roots of People Power (Aurora Javate-De Dios, Petronilo Bn. Daroy \& Lorna Kalaw-Tirol, eds., 1988); STERLING SEAGRAVE, THE MARCos DYNASTY (1988).

69 See generally CeCILIO L. PE \& ALFREdo F. TADIAR, KaTARUNGANG PAMBARANGAY: DYNAMICS OF COMPULSORY CONCILIATION (1979).

${ }^{70} \mathrm{Id}$. at 152 . Of course, the myth of extraordinary American litigiousness since has been debunked. Marc Galanter, Beyond the Litigation Panic, 37 Proc. ACAD. POL. SCI. 18, 26 (1988). See Sally Engle Merry, Sorting Out Popular Justice, in MERRY \& MILNER, POSSIBILITY OF POPULAR JUSTICE, supra note 30, at 38-39, 39 n.9.

71 See PE \& TADIAR, supra note 69, at 152.

72 Id. at 143.

73 Id. at 149; see also Gladys Claridad, Mediation Among Filipinos: Indigenizing the Methods of Mediation Into the Philippine Context (2006) ("the Barangay Justice System was introduced in order to sustain peace and order in the country") (internal citation omitted), available at http://www.ausdispute.unisa.edu.au/apmf/2006/papers/claridad.pdf.

74 John H. Adkins, Philippines 1971: Events of a Year, Trends of a Future, 12 ASIAN SURV. 78, 79-81 (1972). 
program in the United States, ${ }^{75}$ Marcos' creation of the KP system was animated not by access to justice or self-determination, but by their polar opposites, repression and dictatorial control. Indeed, among those trained in the new law were the provincial and city commanders of the Ministry of National Defense, who led the program of impunity. ${ }^{76}$

The KP system was an ingenious method of centralized social control. Abolishing organs of democratic governance and resurrecting the "barangay," or neighborhood, as the basic political unit of the country during the period of dictatorial consolidation, Marcos used these newly created political units as a basis of power. As G. Sidney Silliman observed, the creation of the KP system:

is a step toward the rationalization, under state coordination, of the existing local institutions for dispute settlement. This is politically significant because it reduces the importance of local elites and forestalls the tendency of the rural population to turn for justice to revolutionary alternatives. Village conciliation tends to diffuse potential threats to the existing social system because it focuses on individual differences rather than on systemic problems, and the rhetoric surrounding the promulgation of the decree is an amplification of the ideology that the Marcos government has utilized to increase its legitimacy. ${ }^{77}$

The rhetoric of KP proponents invoked the image of indigenous self-rule "at the root of Filipino culture." $78 \mathrm{Pe}$ and Tadiar claimed that the amicable settlement of disputes on a family and neighborhood level is part of the Filipino identity. ${ }^{79}$ Castro envisioned the creation of "neighborhood paralegal committees" as a "salutary throwback to the pre-Spanish times ... when in all kinds of suits, the case was heard before the old men of the district in

\footnotetext{
${ }^{75}$ H. W. BRANDS, Bound to EMPIRE: The United STATES AND PHILIPPINES 299 (1992).

76 PE \& TADIAR, supra note 69 , at xiv. For a summary of the abuses committed by the Ministry of National Defense and its cohort agencies in this period, see AMNESTY INT'L., REPORT OF AN AMNESTY INTERNATIONAL MISSION TO THE REPUBLIC OF THE PhILIPPINES, 22 Nov.-5 DEC. 1975 (2d ed. 1977).

77 G. Sidney Silliman, A Political Analysis of the Philippines' Katarungang Pambarangay System of Informal Justice Through Mediation, 19 LAW \& SOC'Y REV. 279, 281 (1985).

78 PE \& TADIAR, supra note 69 , at 5.

${ }^{79} \mathrm{Id}$. at 5 . The image of the pacific native is, of course, itself a self-serving colonial creation.
} 
which the litigants lived." 80 Rhetorically, then, indigenous self-determination and access to justice were among the aspirations that animated the birth of modern ADR in the Philippines.

The KP system survived the overthrow of the dictatorship in $1986,{ }^{81}$ and its basic structure has remained unchanged. The barangay remains the country's basic political unit. ${ }^{82}$ Numbering about 40,000 , each is headed by a "punong barangay," or barangay captain. ${ }^{83}$ The barangay captain chairs the KP and, under the KP system, is the person to whom parties must first bring their dispute. ${ }^{84}$ The barangay captain then has fifteen days to settle the matter. ${ }^{85}$ If the dispute does not settle, the barangay captain constitutes a "pangkat," a three-person mediation panel drawn, in turn, from a "lupong tagapamayapa" ("lupon" or peace congregation), also appointed by the barangay captain. This lupon is composed of ten to twenty barangay residents having "integrity, impartiality, independence of mind, sense of fairness, and reputation for probity." 86 Under Philippine law, pangkat members are "quasi-official "persons of authority." 87 They are not remunerated. ${ }^{88}$ Once the barangay captain convenes the pangkat, the pangkat must meet within three days. ${ }^{89}$ The pangkat then has up to thirty days to settle the matter. All told, the KP system has forty-eight days in which to

${ }^{80}$ Id. at xi; see also Gil Marvel P. Tabucanon, James A. Wall \& Wan Yan, Philippine Community Mediation, Katarungang Pambarangay, 2008 J. DiSP. RESOL. 501, 503 (KP system did not introduce "new concept of dispute settlement" but rather "recognize[d] and formalize[d] the tradition of village-centered dispute resolution.").

${ }^{81}$ For a summary of the "People Power Revolution" that overthrew the Marcos dictatorship, see Capulong, supra note 68, at 1116.

82 LOCAL GOVERNMENT CODE OF 1991, REP. ACT No. $7160 \S 384$, (1991), Book 3, p. 158, available at www.gov.ph/downloads/1991/10oct/19911010-RA-7160-CCA.pdf. As of December 31, 2006, there were 42,026 barangays in the Philippines. National Statistical Coordination Bd., Provincial Summary: Number of Provinces, Cities, Municipalities, and Barangays, by Region (Dec. 2006), http://www.nscb.gov.ph/activestats/psgc/NSCB_PSGC_SUMMARY_Dec06.pdf (last visited Oct. 30, 2011).

${ }^{83}$ Barangay captains have a limited term of three years. See Aquino, supra note 66, at 5 .

84 See generally PE \& TADIAR, supra note 69, at 7.

85 Tabucanon, supra note 80, at 509.

86 Id. at 504 (citing LoCAL GOV'T CODE OF 1991, § 399 (a)-(b)).

87 Id. (citing LoCAL Gov'T CODE OF 1991, $\$ 406$ (a)).

88 Id. (citing LOCAL Gov'T CODE OF 1991, § 406 (b)).

${ }^{89} \mathrm{Id}$. at 509. 
settle a claim before it can be allowed to proceed to court. ${ }^{90}$ The KP system has jurisdiction over so-called minor disputes and offenses, both civil and criminal, involving residents of the barangay. These include crimes punishable by imprisonment not exceeding one year or a fine not exceeding five thousand pesos.91 They also include "divorce, spousal abuse, child abuse, theft, assault, land disputes, contract disputes, child abandonment, public drunkenness, slander, and sexual misconduct." 92 Disputants must first use the KP system before going to court. The Philippine Supreme Court has held that a case filed without this prior compliance may be dismissed upon motion of any party. ${ }^{93}$

In the effort to dismantle authoritarian rule following the overthrow of the dictatorship, the Philippine Legislature, in 1991, transferred political oversight of the system from the executive to local and provincial governments, in particular the municipal mayor's office. ${ }^{94}$ Since then, the KP system has been the subject of various reforms, including a USAID-funded initiative to expand and strengthen its reach to the Muslim south, ${ }^{95}$ the further "indigenization" of procedural methods, ${ }^{96}$ and the depoliticization and cultural and gender balancing of mediator panels. ${ }^{97}$ The KP system continues to be politicized, however, this time from local and provincial elites, rather than the national government. In a study of five municipalities, for example, Rachel Aquino found that barangay captains, who were often

$90 \mathrm{Id}$.

91 Tabucanon, supra note 80, at 505-06 (citing LOCAL Gov'T CODE OF 1991, § 399). The October 30, 2011 exchange rate is one American dollar for 42.70 Filipino pesos. EXCHANGE-RATES.ORG, http://www.exchange-rates.org/Rate/USD/PHP/10-29-2011 (last visited Oct. 30, 2011).

92 Tabucanon, et al., Philippine Community Mediation, supra note 80, at 509; see generally Resil B. Mojares, Deborah P. CARnaje \& Linda Siervo CaRnizares, Dispute Processing In Four Cebu Barangays: A SOCIOCUltural STUdy OF THE KaTARUNGANG PAMBARANGAY, 45 (1984).

93 Tabucanon, supra note 80, at 505 (citing Bonifacio Law Office v. Bellosillo, A.M. No. MTJ-00-1308 (S.C. Dec. 16, 2002, citing Administrative Circular No. 14-93, par. IV)).

94 Id. at 503.

95 Richard N. Blue, Emmanuel Leyco [sic] \& Agnes Devanadero, Assessment of the Centers of Local Governance: Implementation of the Barangay Justice Service System (BJSS) Project in Mindanao, Philippines, 33, 38-40, 44 (2002) (Cebuano Stud. Ctr. \& Ministry of Loc. Gov't . 1984), available at http://pdf.usaid.gov/pdf_docs/PDABX610.pdf.

96 Claridad, supra note 73 , at 3.

97 Aquino, supra note 66, at 17. 
beholden to local elites, politicized dispute resolution and recommended that their role be delimited: 98

There is a need to review the role of the punong barangay/barangay captain in view of the fact that he is an elective/political official, because much of the literature, survey, and interviews reveal that many residents do not use the system because of the lack of credibility on the punong barangay to render judgment or facilitate dispute resolution in an impartial manner. ${ }^{99}$

Aquino argued for the "need to depoliticize the whole system and divert cases away from political figures into more credible members of the community." 100 Aquino also found that conciliation panels were only constituted in urban areas, and "often, the disputants do not have a say on its composition." 101 Finally, Aquino found that disputants "hardly have a say on how their cases are to be disposed of."102

For Filipinos disputing outside, or who do not avail themselves, of indigenous systems, the dictatorship-era KP system is structurally designed to be their first encounter with formal third-party and, here, state intervention.

\section{Court-Annexed Mediation and Judicial Dispute Resolution}

Disputants who hurdle the jurisdictional prerequisite of the neighborhood justice system encounter a second series of mediations in court. The Philippine judiciary is a four-tier system. ${ }^{103}$ In the first tier are the metropolitan and municipal trial courts, including Muslim Shari'a circuit courts; in the second are regional trial courts, including Shari'a district

$98 I d$. at 2

99 Id. at 9 .

${ }^{100}$ Id.

${ }^{101} \mathrm{Id}$. at 1 . A barangay captain I interviewed on June 27, 2010, told me that she appointed her husband and friends to the Lupon panel. Interview with Toyang Cabrera, Barangay Captain, Cabanatuan, Nueva Ecija, in Parukot, Nueva Ecija (June 27, 2010).

102 Aquino, supra note 66 , at 1,15 .

103 See SUPREME COURT OF THE PHILIPPINES, available at http://sc.judiciary.gov.ph/PhilJud.swf (last visited Nov. 3, 2010). For a succinct summary of the Philippine political structure, government structure, and legal system, see Milagros Santos Ong, UPDATE: Philippine Legal Research, HAUSER GLOBAL LAW SCHOOL PROGRAM (June 2009), http://www.nyulawglobal.org/globalex/Philippines1.htm (last visited October 20, 2011). 
courts; in the third are various appellate courts, including a special court for governmental officials accused of graft and corruption; and in the fourth is the Supreme Court, the tribunal of last resort. ${ }^{104}$ Litigants are referred to mediation in each of these tiers. The trial courts do it as a matter of policy, and the appellate courts do it on an ad hoc basis. ${ }^{105}$

The designers of the neighborhood justice system also designed courtannexed mediation. In 1991, Tadiar, again with backing from USAID, 106 piloted projects in two jurisdictions, Quezon City and San Fernando, La Union. From these meager beginnings has come a court-annexed mediation (CAM) program now serving more than two-thirds of courts nationwide. ${ }^{107}$ In 2001, the Supreme Court established the Philippine Mediation Center (PMC) ${ }^{108}$ and designated its administrative arm, the Philippine Judicial Academy (PHILJA), to lead the CAM effort. ${ }^{109}$ As of 2010, the PMC operates ninety-eight units across the country and employs 798 mediators. 110 The PMC also operates four mobile CAM programs. ${ }^{111}$ Together with PHILJA, it conducts mediation trainings for court personnel on a regular basis, based primarily on the U.S. facilitative model. ${ }^{12}$

104 See SUPREME COURT OF THE PHILIPPINES, supra note 103.

105 In September, 2010, for example, the Philippine Supreme Court referred to mediation a contentious appeal involving Hacienda Luisita, a sugar plantation owned by the powerful Cojuangco family. Marichu Villaneuva, Hacienda Luisita Welcomes Supreme Court Meidation Panel, THE PHILIPPINE STAR, Sept. 4, 2010, available at http://www.philstar.com/Article.aspx?articleId=608932\&publicationSubCategoryld=63 (last visited Nov. 3, 2010).

106 PhilipPine Judiclal ACADEMY, Operations Manual for the Implementation of Alternative Dispute Resolution in the First and Second Level Courts of the Philippine Judicial System 4 (2004).

107 Philippine Judicial ACAdemy, Philippine Judicial Academy Annual Report 2009 , 3 , available http://philja.judiciary.gov.ph/spublication/PDF/PHILJA\%20Annual\%20Report\%202009. $\operatorname{pdf}(68 \%)$.

108 See PhilipPine Mediation CENTER, http://www.pmc.org.ph/ (last visited Oct. $25,2011)$.

${ }^{109}$ Hon. Ameurfina Melencio Herrera, Court Annexed Mediation (CAM): Making it Work, the Philippine Experience, presented at the International Conference \& Showcase on Judicial Reform, Day 2 (Makati Shangri-La Hotel, Philippines Nov. 28, 2005)

110 Philippine Judicial Academy Annual Report 2009, supra note 107, at 3, 28.

111 Id. at 29.

112 PhILIPPINE JUDICIAL ACADEMY, http://philja.judiciary.gov.ph/seminar.htm (last visited Dec. 9, 2010); Presentation by Department of Justice Undersecretary Linda Malenab-Hornilla, 2010 ADR conference, supra note 10. 
In the Philippine judicial system, all civil cases, including "civil aspects" of certain criminal charges, may be referred to mediation. ${ }^{113}$ In trial court, mediation is officially part of the pretrial phase and occurs in two stages. First, the court may order parties to report to a PMC office. ${ }^{114}$ There, PMC mediators "automatically become[] Officer[s] of the Court,"115 and parties can admit facts or submit documents to them. ${ }^{116}$ PMC mediators may convene the parties repeatedly; the form they use allows for ten sessions, for example (though I was told by PMC personnel that they can convene parties even more times than that). They are volunteers compensated on a per-case basis and settlement is compensated nearly three times more than impasse. ${ }^{117}$ A plaintiff's failure to appear "shall" result in the dismissal of the action "with prejudice, unless otherwise ordered by the court."118 A defendant's nonappearance allows the plaintiff to present evidence ex parte "and the court shall render judgment on the basis thereof." 119

\begin{tabular}{ccccc}
\hline 113 & Divina & Luz P. Aquino-Simbulan, Developments in Philippine Mediation for \\
Court & Cases & 2 & $(2009)$, & available
\end{tabular} http://philja.judiciary.gov.ph/spublication/PDF/PHILJA\%20Annual\%20Report\%202009. pdf (last visited June 6, 2011). So-called "mediatable" cases include "[a]11 civil cases, settlement of estates and cases covered by the Rule on Summary Procedure, except those which by law may not be compromised; [c]ases cognizable by the Lupong Tagapamayapa under the Katarungang Pambarangay Law; [both civil and criminal cases][;] [t]he civil aspect of BP22 cases; and [t] he civil aspect of quasi offenses under Title 14 of the Revised Penal Code." Operations Manual, supra note 106, at 16.

114 Section II.A.4, Operations Manual, supra note 106, at 19. The order to mediate is mandatory. Id. at 18. Parties may only elect to opt out of a mediation after that first meeting, in which the PMC office orients them to the mediation process. Id. at 19.

115 Section II.B.8, Operations Manual, supra note 106, at 20.

116 Id. at 18.

117 Mediators are paid 1,000 pesos (\$23) if a case settles; 350 pesos $(\$ 8)$ if it fails to settle. Interview with Floris Inocencio, staff, Philippine Mediation Center in Paranaque, Phil. (July 13, 2010).

118 Operations Manual, supra note 106, at 18 (citing Sec. 4, Rule 18, Revised Rules of the Court of the Philippines, 1997 Rules of Civil Procedure (1997, amended 1998)), available at http://www.chanrobles.com/1997rulesofcivilprocedure.htm.

119 Id. at 18 (citing Sec. 5, Rule 18, Revised Rules of the Court of the Philippines, 1997 Rules of Civil Procedure (1997, amended 1998)), available at http://www.chanrobles.com/1997rulesofcivilprocedure.htm._See also id. at 20 (stating that mediator "must report" subsequent nonappearance of parties ordered to mediation). But see id. at 29 (stating that only initial appearance is compulsory as "parties cannot be forced to mediate"). 
If parties do not reach settlement through this process, they go through "judicial dispute resolution" (JDR). JDR is a "series of activities undertaken for failed mediation cases" 120 in which a non-presiding judge "becomes a conciliator, early neutral evaluator and/or mediator."121 Regional trial court Judge Divina Luz Aquino-Simbulan describes that "[a]s a conciliator, the JDR judge persuades parties to reconsider their reluctance to compromise." She further notes that "[a]s an early neutral evaluator, the JDR judge gives a confidential, reasoned oral evaluation but non-binding opinion on the strengths and weaknesses of each party's case and their chances of success." 122

JDR was institutionalized through the Justice Reform Initiative Support (JURIS) project, a Canadian-funded initiative. ${ }^{123}$ As the JURIS Design and Management Committee stated, their project "carries court-annexed mediation one step further by having the pre-trial judge undertake a second attempt to settle the dispute when the first mediation fails." 124 During the JDR process, judges have between thirty and sixty days to settle the case. ${ }^{125}$ As of 2010, there were 226 judges trained in JDR. ${ }^{126}$

On the appellate level, the Court of Appeals and Supreme Court also refer cases to mediation. ${ }^{127}$ Appellate Court Mediation (ACM) now exists in the Manila and Cagayan De Oro regions, and between 2007 and 2009, the number of cases referred to ACM went from twenty-seven to $296-$ a $1,000 \%$ jump. ${ }^{128}$

120 Operations Manual, supra note 106, at 24. Judicial dispute resolution originated from Canada, which sponsored JURIS project. See Cappelletti, supra note 12, at 291 (noting that judicial mediation within a pretrial conference is "now becoming the norm in many, if not all, the Common Law Provinces.").

121 Aquino-Simbulan, supra note 113, at 29.

122 Id. at 6.

123 The JURIS Project was a five-year project undertaken by the Canadian International Development Agency and the Philippine Government, which commenced in 2003. It had four components: (1) judicial education and mediation/ADR strengthening; (2) reform advocacy; (3) technical studies; and (4) project management. Operations Manual, supra note 106 , at 5 .

$124 \mathrm{Id}$. at 4.

125 Aquino-Simbulan, supra note 113 , at 6.

126 Malenab-Hornilla, supra note 112.

127 See, e.g., Edu Punay, Supreme Court Starts Mediation on Luisita Row, PHILIPPINE STAR (Sept. 11, 2010), available at $\mathrm{http}: /$ www.philstar.com/Article .aspx?articleld=610912\&publicationSubCategoryld=63.

128 Philippine Judicial Academy Annual Report 2009, supra note 107, at 28. 
As of the end of $2009,68 \%$ of all Philippine courts use some form of mediation or conciliation. 129 And as of then, the PMC had successfully mediated 96,158 out of 238,672 cases referred by trial courts; 108 out of 579 cases referred by appellate courts; and 5,831 out of 22,103 cases referred to JDR-a $67 \%, 35 \%$, and $40 \%$ settlement rate, respectively. ${ }^{130}$

\section{The Alternative Dispute Resolution Act of 2004}

The Philippines took another stride toward institutionalizing mediation in 2004. That year, the Alternative Dispute Resolution Act declared:

the policy of the State to actively promote party autonomy in the resolution of disputes or the freedom of the party to make their own arrangements to resolve their disputes. Towards this end, the State shall encourage and actively promote the use of [ADR] as an important means to achieve speedy and impartial justice and declog court dockets. ${ }^{131}$

The Act created the Office of Alternative Dispute Resolution, which was tasked with "promot[ing], develop[ing] and expand[ing] the use of ADR in the private and public sectors." 132 Six years later, in 2010, the Department of Justice issued a set of rules and regulations implementing the Act. ${ }^{133}$

Mediation thus permeates the Philippine legal landscape. Disputants seeking third-party or state intervention, particularly in rural areas, first may undergo some form of mediation through an indigenous process. Thereafter, disputants must mediate through the neighborhood justice system prior to going to court. In court, they then encounter mediation at both the trial and appellate levels. With broad support from the local ADR community and continuing Western assistance and funding for ADR reform in the country, it

${ }^{129} \mathrm{Id}$. at 3.

${ }^{130}$ Malenab-Hornilla, supra note 112.

131 Alternative Dispute Resolution Act of 2004, Republic Act No. 9285, § 2 (2004), available at http://philippinelaw.info/statutes/ra9285-alternative-dispute-resolution-actof-2004.html.

132 Id. $§ 49$ (a).

133 The Philippines, Bureau of East Asian and Pacific Affairs, THE UNITED STATES DEPARTMENT OF STATE, (June 3, 2011) http://www.state.gov/r/pa/ei/bgn/2794.htm (last visited Oct. 30, 2011). The 2010 ADR conference, supra note 10, marked the release of these rules. 
is fair to say that the influence of U.S.-style mediation will only continue to grow. ${ }^{134}$

\section{ACCESS TO JUSTICE AND SELF-DETERMINATION IN POSTCOLONIAL COMMUNITY MEDIATION}

Despite the insidious ways it has been used, community mediation remains a compelling method of dispute resolution because it has great potential to promote access to justice and self-determination. Less costly and less formal than litigation, it is a much more accessible process, particularly for parties who cannot afford an attorney. Less rigid than litigation or arbitration, it allows participants to determine their own outcomes. ${ }^{135}$ In this section, I discuss access to justice and self-determination in postcolonial community mediation specifically. As I have mentioned, proponents who find hope in mediation in the postcolonial setting offer prescriptions from both the top-down and the bottom-up, from structural reform to counterhegemonic practice.

\footnotetext{
${ }^{134}$ See, e.g., Judicial Settlement Conference for Judges on Judicial Dispute Resolution (Skills-Based Course), PHILIPPINE JUDICIAL ACADEMY, http://philja.judiciary.gov.ph/news/2011/judicial_settlement.htm (last visited June 6, 2011) (discussing JDR Expansion Program). Without exception, all the participants at the 2010 ADR conference, supra note 10, supported the expansion of ADR and mediation in the Philippines.

135 Timothy Hedeen observes that the principle of self-determination "cannot be overstated." Timothy Hedeen, Coercion and Self-Determination in Court-Connected Mediation: All Mediations are Voluntary, But Some are More Voluntary Than Others, 26 JUST. SYS. J. 273, 274 (2005); see also Standard I, AMERICAN BAR ASSOCIATION MODEL STANDARDS OF CONDUCT FOR MEDIATORS (2005), available at www.adr.org/si.asp?id=3827 ("A mediator shall conduct a mediation based on the principle of party self-determination. Self-determination is the act of coming to a voluntary, un-coerced decision in which each party makes free and informed choices as to process and outcome. Parties may exercise self-determination at any stage of a mediation, including mediator selection, process design, participation in or withdrawal from the process, and outcomes... A mediator shall not undermine party selfdetermination by any party for reasons such as higher settlement rates, egos, increased fees, or outside pressures from court personnel, program administrators, provider organizations, the media or others.").
} 


\section{A. Access to Justice and Self-Determination: Co-extensiveness and Conflict}

Access to justice and self-determination are concepts with co-extensive and conflicting dimensions. Traditionally understood, access to justice means access to the rule of law, which, in turn, means access to courts and lawyers. The principle is, of course, the result of the great democratic revolutions that overthrew absolutism. ${ }^{136}$ Deborah Rhode repeatedly has taken the profession to task for failing to live up to this aspiration. ${ }^{137}$ In addition to court reform, pro bono service, and self-help, she advocates for well-designed ADR methods as one avenue by which to access justice. ${ }^{138}$ In contrast to the traditional view of justice as the vindication of rights through courts and the rule of law, justice in mediation "entails empowerment of individuals to shape decisions about their own lives and conflicts on terms that are meaningful to them."139 Joseph Stulberg sees this concept of individual selfdetermination and popular justice as Rawlsian "pure procedural justice."140 In mediation, access to justice and self-determination are co-extensive to the extent that mediation allows for the use of both legal and nonlegal norms in the resolution of disputes, a process conducive to a more inclusive quality of justice. ${ }^{141}$

136 See Cappelletti, supra note 12 , at 294 ("Until that time, civil societies were divided into social strata and to each of them a different legal order, even different courts, applied. What was to emerge from the liberal-bourgeois Revolution was the ideal of the Rule of Law state, or Rechtsstaat, where the law has a general character and the basic principle is that all are equal before the law.") For an entertaining discussion of such revolutions in Europe in the 19th century, see MARY GABRIEL, LOVE \& CAPITAL: KARL \& JENNY MARX AND THE BIRTH OF A REVOLUTION (2011).

137 Deborah L. Rhode, Access to Justice: Connecting Principles to Practice, 17 Geo. J. LegAL ETHICS 369 (2004); see generally DEBORAH L. RHODE, ACCESS TO JUSTICE (2004).

138 Id.

139 Craig A. McEwen \& Laura Williams, Legal Policy and Access to Justice Through Courts and Mediation, 13 OHIO ST. J. ON DiSP. RESOL. 865, 866 (1998).

140 Joseph B. Stulberg, Mediation and Justice: What Standards Govern?, 6 CARdOzo J. CONFLICT RESOL. 213, 227 (2005). Stulberg identifies six principles of pure procedural justice: voluntariness; inalienability of interests; publicity of outcomes; dignity and respect; informed decisionmaking; and toleration of conflicting fundamental values. Id. at 227-28.

${ }^{141}$ See Clark Freshman, The Promise and Perils of "Our" Justice: Psychological, Critical and Economic Perspectives on Communities and Prejudices in Mediation, 6 CARDOZO J. CONFLICT REsol. 1 (2004); Katherine R. Kruse, Learning from Practice: 
The conflict inheres in how self-determination exceeds the demand for "access." As I have discussed elsewhere, this demand, indeed the ADR movement itself, coincided with the so-called "right turn" in American politics in the mid-1970s: ${ }^{142}$ Signaling the ascendancy of public interest lawyering and liberal legalism over its more militant predecessors (i.e., "people's," "movement," and "poverty" lawyering, and the radicalism of the New Left), "access to justice" in this historically specific sense was a political retreat from the critique that the legal system was, by design, incapable of providing justice. According to this critique, the legal system functioned against the very people - those disenfranchised and marginalized from the formal justice system - that mediation, in particular community mediation, specifically sought to empower. ${ }^{143}$ Indeed, this realization is what led feminists and the community justice movement to support ADR in the first place. In this sense, the demand for access to a self-determined process is an oxymoron: why would empowered individuals "seek access" to a process they themselves organically create, manage, and sustain? ${ }^{144}$ This first contradiction is especially problematic in the postcolonial context, where, as here, a primary sponsor of ADR reform happens to be the former colonizer.

What ADR Needs from a Theory of Justice, 5 NEV. L.J. 389 (2005); Jacqueline NolanHaley, Court Mediation and the Search for Justice Through Law, 74 WASH. U.L.Q. 47 (1996); Ellen A. Waldman, The Concept of Justice in Mediation: A Psychobiography, 6 CARDOZO J. CONFLICT RESOL. 247 (2004). But see Cain, supra note 3, at 340 ("[I]n so far as [informal law] constitutes' its subjects in non-individual ways, then this informal procedure is not law. It must be some other form of justice or of social control.").

142 Eduardo R. C. Capulong, Client Activism in Progressive Lawyering Theory, 16 Clinical L. Rev. 109, 140 (2009); see also David M. Trubek, Critical Moments in Access to Justice Theory: The Quest for the Empowered Self in ACCESS TO CIVIL JUSTICE 107-28 (Allan C. Hutchinson ed., 1990) (discussing access to justice movement in context of rise of public interest law movement in 1970s).

143 See Capulong, supra note 142, at 132-53 (discussing ideological shift from "people's" and "poverty" lawyering challenging the legal system, to "public interest" lawyering seeking "access" to it).

144 Cf. Cain, supra note 3, at 340:

The use of legal means to reinforce community or neighbourhood ties thus involves a contradiction. Informal law is a contradiction in terms so far as the working class is concerned. In so far as informal law is law it is destructive of collectivity, the only source of countervailing power to capital. In so far as informalism does not destroy collectivity, that is in so far as it constitutes its subjects in non-individual ways, then this informal procedure is not law. It must be some other form of justice or of social control.. 
In this setting, accessing the justice offered by these reforms very well may be antithetical to self-determination.

Second, in its most idealized form, mediation as a normatively expansive, self-determined, process may yield forms of justice over and above, and, theoretically, even contrary to that which the state and formal legal system can provide or, indeed, will allow. Informal or popular justice, in other words, can be subversive. Thus, at its outer reaches, selfdetermination can undermine the legitimacy and power of the very state and legal system attempting to provide "access to justice" in the first place.

Finally, self-determination has specific features in the postcolonial context. In international law, it is a fundamental, collective right. ${ }^{145}$ People in the former colonies have the right to sovereignty, that is, to rule independently and to make law. ${ }^{146}$ Thus, where, as here, the former colonizer remains intimately involved with the legal apparatus, ${ }^{147}$ we need to examine the collective, national dimensions of individual claims raised in community mediation and ask how they might be furthered or undermined in discrete cases.

With this context in mind, I discuss in this section how we might think of access to justice and self-determination in community mediations in the Philippines and other postcolonial settings.

\section{B. Access to What?}

If community mediation provides access to justice, what sort of justice can it provide? Procedural justice does not always result in normative justice, of course. ${ }^{148}$ And normative justice cannot possibly be "neutral." Hence, access to justice " $m u s t$ be defined in terms of ensuring that legal and judicial outcomes are just and equitable." 149 Indeed, mediation's promise is precisely

145 U.N. CHARTER ART. 1, para. 2.

146 Id.

147 One classified memorandum recently made public by Wikileaks described the relationship between the United States and the Philippines as "just short of incest." See James Cordova, Wikileaks: US-Phillipine Relations "Just Short of Incest", ASIANCORRESPONDENT.COM (Aug. 26, 2011), http://asiancorrespondent.com/63445/usphilippine-relations-just-short-of-incest-wikileaks-cable/ (last visited Oct. 25, 2011).

148 Melanie Greenberg, Mediating Massacres: When "Neutral, Low-Power" Models of Mediation Cannot and Should Not Work, 19 OHIO ST. J. ON DISP. RESOL. 185 (2003).

${ }^{149}$ U.N. Development Programme, Access to Justice Practice Note 6 (Sept. 3, 2004), available at http://www.undp.org/governance/docs/Justice_PN_English.pdf (emphasis added). 
in allowing for a range of substantive outcomes broader than that accessible through litigation. What type of justice do disputants actually get? What can they get?

As part of the "third wave" of the global access to justice movement, 150 ADR-community mediation especially-always has envisioned a grassroots, bottom-up approach to justice. As R. Sudarshan summarizes, "[ $t]$ he 'first wave' ... was legal aid. The 'second wave' ... included public interest litigation. The third wave goes beyond case-centered advocacy [and] represents a broader panoply of less adversarial and less complex approaches." 151

Hence, the types of justice parties can access in and through community mediation can span the gamut. The classic binary involves outcomes based on legal and non-legal norms, between formal and informal justice. This binary, however, belies the complexities of mediation justice. Informal justice can be either regressive or progressive. Bookending the twentieth century, for example, is mob justice leading to the lynchings of AfricanAmericans in the early part and the public executions of former Eastern European despots in the latter. Within more peaceful bounds, informal justice can be "second class" or liberatory. ${ }^{152}$ Mediation can surreptitiously reproduce gender and racial biases, for example, ${ }^{153}$ or free parties from legal obligation. ${ }^{154}$ Hence, one can think of justice in mediation on a continuum, on one end characterized by individualized outcomes disfranchised by the guarantees of, or in any event within, the prevailing legal and social order, and on the other by collective outcomes gesturing towards a new social order.

150 See Cappelletti, supra note 12, at 289.

${ }^{151}$ R. Sudarshan, Avatars of Rule of Law and Access to Justice: Some Asian Aspects, U.N. Devel. Programme, Solution Network of Asia-Pacific, 644, 655 (2009), available at http://www.snap-undp.org/lepknowledgebank/Default.aspx. ("This is an essay that expresses an optimism of will in the face of pessimism of analysis about prospects for advancement of an appropriate form of the rule of law and access to justice to people who now bear the burdens of burgeoning inequality, discrimination, and multiple injustices.").

152 See, e.g., Richard Delgado, et al., Fairness \& Formality: Minimizing the Risk of Prejudice in Alternative Dispute Resolution, 1985 WIS. L. REV. 1359 (1985).

153 Delgado, supra note 152; Trina Grillo, The Mediation Alternative: Process Dangers for Women, 100 YALE L. J. 1545 (1991).

154 See, e.g., STATE OF CONNECTICUT JUDICIAL BRANCH, Foreclosure Mediation Program, available at http://www.jud.ct.gov/foreclosure/. 
Community mediation justice-and for that matter any notion of justice-is, as Maureen Cain put it, "standpoint specific."155 Applying "a materialist theory of justice, from a working class standpoint," Cain identifies four types: professionalized justice, "incorporated" or "colonised" justice, populist justice, and collective justice. ${ }^{156}$ Professionalized, incorporated/colonized, and populist justice all obscure the standpoint from which justice is normatively evaluated, Cain argues. ${ }^{157}$ As the form of justice most associated with liberal legalism, ${ }^{158}$ Cain observes that professionalized justice "has become synonymous with the concept of justice itself," that is, individualized, occupational, and having "no object other than itself." 159 Incorporated or colonized justice, on the other hand, is "a form of adjudication ... taken over by or embodied within either an agency of capital itself or an agency of the state."160 An example is the Better Business Bureau. ${ }^{161}$ Populist justice views society as an organic whole, composed of separate, classless, and, again, independently constituted individuals. ${ }^{162}$ Populist justice, Cain argues, does not claim to be a neutral adjudicator, but a "true" adjudicator; 163 it is the form of justice most inimical to working-class interests. Here, truth is not standpoint-specific but "unproblematic and total." 164 By contrast, collective justice is characterized by, among other features, open and explicit working-class identification and a collective client/subject to which it is accountable. ${ }^{165}$ For the working class, Cain argues, collective justice is the ideal. ${ }^{166}$

155 Cain, supra note 3 , at $335,341$.

156 Id. at 340; see also Ugo Mattei, A Theory of Imperial Law: A Study on U.S. Hegemony \& the Latin Resistance, 10 IND. J. GLOBAL LEGAL. STUD. 383, 389 (2003) ("rule of professional law").

157 Cain, supra note 3, at 341-42.

158 Id. at 348.

$159 \mathrm{Id}$. at $348-49$.

$160 \mathrm{Id}$. at 353 .

161 Id.

$162 \mathrm{Id}$. at $360-61$.

163 Cain, supra note 3, at 361 .

164 Id.

165 Id. at 343-46.

166 Id. Sally Engle Merry further typologizes "popular justice"-which I take to include Cain's definition of collective and populist justice-into four cultural traditions: reformist, socialist, communitarian, and anarchic. Merry, supra note 30, at 32. Merry observes, is "a judicial institution located on the boundary between local ordering and state law with ambiguous and shifting relations to each." Id. 
Extending Cain's perspective and typology to postcolonial settings yields two corollary principles. ${ }^{167}$ First, because ruling national elites benefit independently from ADR reform, the concept of "justice" cannot be delimited to the nationalistic. The postcolonial period often results in the continued economic and political alliance between former colonizer and national elite, but the national elite has interests of its own, independent of its benefactor. Hence, justice in postcolonial settings must be defined from the perspective of the nationally disenfranchised and marginalized, here the Philippine poor and working class. Second, community mediation justice is not delimited to certain, principally professionalized and incorporated, forms. It allows for, and, in postcolonial settings, ought to promote, collective justice-that is, standpoint-specific outcomes consistent with a postcolonial, not simply nationalist, but working-class, agenda. In other words, genuine access to justice in postcolonial settings requires both the provision of the forum and the provision for, indeed pursuit of, specific outcomes.

\section{Self-Determination: Individual and Collective}

Self-determination has similar, added, dimensions in the postcolonial setting. Individual self-determination is, as mentioned, of central importance in mediation, its value measured, as Jacqueline Nolan-Haley has argued, through the principle of informed consent. ${ }^{168}$ Nolan-Haley's enduring lesson is that individual will is socially structured (though, in dialectic fashion, I hasten to add, not necessarily determined) by social context. To be meaningful, individual choices must be informed. Given the juridical nature of dispute resolution, and, therefore, dominance of lawyers in mediation, informed consent often is discussed in terms of legal prerequisites, or the need to educate parties about their legal rights and options. But disputes are, of course, multi-dimensional. Beyond their legal aspects, they have personal, economic, cultural, political, emotional, and other dimensions. Arguably, therefore, parties' informed consent ought to extend to all these considerations.

167 Cain explicitly delimited her analysis to advanced capitalist states. Cain, supra note 3 , at 336-37.

168 See Jacqueline M. Nolan-Haley, Informed Consent in Mediation: A Guiding Principle for Truly Educated Decisionmaking, 74 NOTRE DAME L. REV. 775, 776 (1999); Jacqueline M. Nolan-Haley, Self-Determination in International Mediation: Some Preliminary Reflections, 7 CARDOZO J. CONFLICT RESOL. 277, 278 \& n.7 (2007) (citing various Model Standards of Conduct for Mediators). 
The United States left an enduring colonial legacy in the Philippines, and it continues to dominate the country politically, economically, socially, culturally, and legally. Indeed, a U.S. State Department cable recently publicized by WikiLeaks quotes National Defense Undersecretary Ricardo Blancaflor, head of the Philippine Anti-Terrorism Task Force, as saying that the U.S.-Philippine relationship is "just short of incest." 169 The United States created the Philippine legal system and profession, which it modeled after its own. It created the Philippine judiciary and the country's first law firms. ${ }^{170}$ The Americans founded the Philippines' first law school. Its founding dean, George Malcolm, later became a Philippine Supreme Court justice. ${ }^{171}$ Malcolm apparently was proud of saying that his contemporaries on the high court were former students. ${ }^{172}$ More to the point, the United States remains heavily involved in Filipino dispute resolution. Through the ABA, USAID, World Bank, and other institutions, as mentioned, the United States has sponsored, and continues to sponsor, reforms aimed at promoting, structuring, and restructuring Filipino community mediation.

This continued U.S. dominance of Philippine affairs in general and U.S. sponsorship of the ADR reform in particular is the social context structuring individual self-determination in community mediation in the Philippines. To be meaningful, therefore, individual consent must be informed by this social context in its varying dimensions, not just the legal, but the political, economic, social, and cultural as well. Here, the theoretical basis for ensuring informed consent, it seems to me, is the international right to selfdetermination, that is, the collective right of nations and peoples to chart their destiny free from neocolonial compulsion or interference. ${ }^{173}$ Indeed, the collective right to self-determination is the mirror image of neocolonial

169 See supra note 147.

170 See DEZALAY \& GARTH, supra note 8 , at 76-77. For an insightful look at the Philippine legal elite, which has close ties to the U.S. legal elite, and which has engineered-and continues to engineer, with the assistance of USAID, World Bank, and Asian Development Bank, the transformation of the Philippine legal system, including the propagation of U.S.-style ADR, see $i d$. at 51-61, 76-89, 132-41.

${ }^{171} \mathrm{Id}$. at $86-87$.

$172 \mathrm{Id}$. at 87.

173 See, e.g., Bereket Habte Selassi, Self-Determination in Principle and Practice. The Ethiopian-Eritrean Experience, 29 COLUM. HUM. RTS. L. REV. 91,94 (1997). 
domination: it is a fundamental human right-jus cogens-bearing political, economic, cultural, and social dimensions. ${ }^{174}$

There are obvious similarities between the principle of individual selfdetermination in mediation and the right to collective self-determination in international law. But grounding one in the other presents formidable theoretical and practical challenges. To begin with, the right belongs to "collectivities known as 'peoples,' not to individuals." 175 I leave for another day a deeper examination of the relationship between the principle of individual self-determination in mediation and right to collective selfdetermination in international law. Here, I ask only tentatively how, if at all, the latter might apply in community mediation settings. The doctrinal evolution of the collective right to self-determination seems to point in the right direction. ${ }^{176}$ Arguing that the right ought not be delimited to collectivities, for example, Hurst Hannum observes that "meaningful content to self-determination" may be found in "the right of individuals and groups to participate effectively in the economic and the political life of the country." 177 Hurst states, "ensuring participation opens up a whole range of possibilities, ranging from representation in the central government to different forms of federalism, consociationalism, and autonomy."178 This range of possibilities arguably includes participation in the legal system and dispute resolution. Second, because the international right has broad dimensions-legal, political, economic, social, and cultural-the inquiry requires a searching exploration of how a neocolonial agenda is manifested, if at all, in individualized disputes between nationals. There are subjective and objective elements in any dispute. Applying the international right in community mediation requires an objective exploration of whose interests, if anyone's, promotes neocolonial interference, which, in turn, raises the question of who (the mediator, the disputing parties, or third party advocacy organizations) should engage in such an inquiry. Third, where the neocolonial, here U.S., agenda does manifest itself-for example in the disregard of indigenous dispute resolution or use of community mediation by

174 See, e.g., Lam, supra note 50, at 155 . In her article, Lam implies that indigenous peoples' right to self-determination is the key to opposing the Washington Consensus. Id. at. 148 .

175 Hurst Hannum, The Right to Self-Determination in the Twenty-First Century, in CLAUDE \& WESTON, supra note 174, at 243.

176 Id. at $243-44$.

177 Id. at 245 (emphasis added).

${ }^{178} \mathrm{Id}$. 
neocolonial political allies-the question arises as to how individuals ought to exercise the right.

With these specific issues relating to access to justice and selfdetermination in postcolonial community mediation in mind, I return to the Philippine community mediation experience.

\section{REALIZING ACCESS TO JUSTICE AND SELF-DETERMINATION IN PHILIPPINE COMMUNITY MEDIATION}

Ensuring genuine access to justice and self-determination in Philippine community mediation requires both structural reform and counter-hegemonic practice. In this section, I return to the three axes I mentioned in Part Iprogram ideology and design, mediator role and practice, and external political and organizational support for disputing parties-and summarize various changes that need to be made with respect to each of the three systems-indigenous dispute resolution, the neighborhood justice system, and court-annexed mediation-to promote these goals. With respect to counter-hegemonic practices, the task, as Cain cogently argues, "is to notice ... pre-figurative institutions where they emerge, and to identify their salient features."179

\section{A. Understanding, Recognizing, Respecting, and Supplementing Indigenous Dispute Resolution}

The collective right to self-determination endows indigenous peoples with the dual right to use their own laws and dispute resolution methods "as the primary means to redress grievances" and participate fully in state processes "if they so choose." 180 Thus, in the dispute-resolution context, the right to self-determination contemplates what Jennifer Franco has called a "plural juridical field," 181 that is, the co-existence of customary and state law. Unfortunately, as Cisnero has observed, state response to indigenous law and

179 Cain, supra note 3, at 341 .

180 See Osi, supra note 33, at 176, \& n.37 (emphasis added) (citing UNDRIP, Art. 5, 31(1)). "Indigenous peoples have the right to maintain and strengthen their distinct, political, legal, economic, social and cultural institutions, while retaining their right to participate fully, if they so choose, in the political, economic, social and cultural life of the State." Id.

181 Jennifer C. Franco, Peripheral Justice? Rethinking Justice Sector Reform in the Philippines, 36 WORLD DEV'T 1858, 1862-63 (2007). 
dispute resolution in the Philippines, as elsewhere, is often to discount or coopt it. ${ }^{182}$ In his presentation at the 2010 ADR conference, for example, former Department of Environment and Natural Resources undersecretary Elmer Mercado recommended the agency to commit to "[d]ocumentation and integration of non-traditional and customary practices to mediation and ADR."183

Little is known about Filipino indigenous dispute resolution. I therefore echo Cisnero's call here for further study of such processes. In terms of what we do know: customary laws and tribal elders remain the main instruments for resolving indigenous disputes. In a 2005 pilot study of indigenous people's rights to ancestral domains, for example, $52 \%$ of respondents reported using customary law to resolve their disputes. ${ }^{184}$ Only $13 \%$ of respondents reported that they referred the dispute to a government institution. ${ }^{185}$ Similarly, nearly $72 \%$ of respondents used barangay councils and councils of elders as the venue for resolving these conflicts. ${ }^{186} \mathrm{In}$ addition, therefore, I echo Cisnero's call for indigenous law and dispute resolution systems" "primary" and "special" jurisdiction over certain offenses. ${ }^{187}$

At the same time, indigenous dispute resolution cannot be romanticized. As David Pimentel has observed, "complete independence of customary courts will open the door to human rights violations in those institutions. Traditional law and traditional values, in many cultures, violate modern and

182 Cisnero, supra note 51 , at 93.

1832010 ADR Conference, supra note 10 (emphasis added).

1842005 Pilot Study on the Diagnosis of Indigenous People's Rights to Ancestral Domains in the Philippines, Book I: The Study \& its Findings, available at http://www.nscb.gov.ph/metagora/default.asp.

185 Id.

$186 \mathrm{Id}$.

187 Cisnero, supra note 51, at 121 . But see Merry, supra note 30 , at $46-47$ ("Reviving precolonial law is difficult ... The customary law of the colonial period is a construct of the colonial era, formed in the interaction between European law and indigenous ways of handling differences. Reintroducing precolonial law into the vastly different social conditions of postcolonial countries is problematic.") (internal citations omitted). See also Lam, supra note 50, at 152 ("A prior indigenous social order does not yield automatically to a later statist order, particularly when, as is the case today, modern international law has repudiated the doctrine that territory may be lawfully acquired through conquest or other forms of coercion."). 
otherwise widely-accepted principles of gender equality or child protection." 188

The national constitution and international human rights conventions therefore have to provide a check on indigenous dispute resolution methods insofar as they have the potential to violate the fundamental human rights of women, children, ethnic or political minorities, or other persons and groups. Pimentel provides a framework by which this may be accomplished. Discussing legal pluralism in Mozambique, he argues for an approach that "maximizes" customary law by presumptively applying it "wherever it can . . . and that limits review of customary court decisions to the narrowly-tailored questions of human rights and due process."189 Instead of exercising appellate review over customary court decisions, Pimentel argues for collateral review in which state courts are empowered to overturn customary court decisions "only to the extent [they] violate[] principles reflected in a national constitution or in international human rights instruments that the country has signed or ratified." 190 Pimentel also argues for customary courts' presumptive jurisdiction over most rural disputes, observing, "access to justice issues alone suggests that the rule of law is better served when most cases enjoy the timely, responsive, and cost-effective adjudication that customary courts provide, particularly outside of urban centers."191

In the Philippines, dispute resolution under pure indigenous methods and the state neighborhood justice system is often blurred. ${ }^{192}$ This is problematic for two reasons: it undermines the integrity of indigenous processes and compromises parties' right to participate in one or the other, or both. To fully ensure access to justice and self-determination, therefore, a clear distinction between indigenous processes and the neighborhood justice system must be made. A bright-line distinction would also bolster our understanding of indigenous processes, prevent state cooptation of these processes, and make possible the implementation of Pimentel's collateral review framework. Separating the indigenous from the state-sponsored would clarify our object

188 David Pimentel, Legal Pluralism in Post-colonial Africa: Linking Statutory and Customary Adjudication in Mozambique, 13 YALE HUM. RTs. \& DEV. L.J. 59, 81-82 (2011); see also Cohen, supra note 3, at 344 ("culture" has its downside, for example sexism and superstition).

189 Pimentel, supra note 188 , at 82.

$190 \mathrm{Id}$. at 84 (internal citation omitted).

191 Id. at 95 (internal citation omitted).

192 Aquino, supra note 66, at 16. 
of inquiry, the boundaries of each, and therefore the points at which state review of narrow human rights and due process questions can be made.

\section{B. Transforming the Neighborhood Justice System}

The neighborhood justice (KP) system undermines access to justice and self-determination in at least two ways: it is a mandatory, jurisdictional, prerequisite to the use of the court system, and it is gender and politically biased. This should not be surprising given that the system's overarching purpose is social control from above and not justice from below. As I discuss in Part II, this dictatorship-era creation was aimed at channeling social discontent into organs of state power, and, there, individuating and depoliticizing it, a process Richard Abel has elaborated upon. He states, "[w]hen the state grants legal rights and establishes means of enforcementformal or informal-it inevitably undermines the efforts of the oppressed to help themselves, thereby fostering dependence. Because bourgeois legal rights are assigned to individuals, their pursuit encourages individualism and distracts from, or actually inhibits, collective action." 193

Little has changed from these beginnings. In a 2002 USAID-funded study that sought to strengthen the implementation of the KP system in the Muslim south, the site of a decades-long war between the Philippine government and Muslim secessionists, for example, Richard Blue, Emmanuel Leyco [sic] and Agnes Devanadero write that "peace and harmony," not the substantive resolution of the poverty and racism causing that war, were the desired goals. ${ }^{194}$ In lauding the potential of the KP system to peacefully resolve disputes, these authors cite the decline of crime in the area-curiously excepting casualties of that war. ${ }^{195}$ Similarly, the postdictatorship transfer of KP jurisdiction from the national to local government has meant only that, today, parties must submit to local political elites and no longer the dictatorship. ${ }^{196}$ In her study of KP cases, Aquino found that there remains an inherent political bias in the neighborhood justice system because the barangay captain, an elective office, chairs it, and therefore is

193 The Polttics of INFORMal JustiCe, Vol. 2, 8 (Richard L. Abel ed., 1982).

194 Blue, supra note 95, at vi-vii.

195 Id. at vii.

196 This transition has actually caused confusion over whether the Department of Justice or the Department of Interior and Local Government has jurisdiction over the KP. Interview with Rachel Aquino, Mediators Network for Sustainable Peace in Quezon City, Phil. (July 13, 2010) (on file with author). 
predisposed against political opponents. ${ }^{197}$ This is confirmed by Cobbie Palm, a pro-"fisher folk" advocate in Dumaguete, who told me that he had to "disengage from the KP system because of the KP's loyalty to [fishing] capitalists." 198 Aquino therefore makes the sensible recommendation to depoliticize the process by removing mediation functions from that office. ${ }^{199}$ Aquino also recommends the creation of a board to select lupon members. Right now, barangay captains have sole authority to appoint mediators. ${ }^{200}$ The creation of such a board, she argues, would promote balance in the lupon both in terms of sectors represented and gender. ${ }^{201}$ Aquino found that lupon members are overwhelmingly middle-aged, Christian males, often with ties to the barangay captain. 202 With the argument that the KP system be optional, I echo these recommendations here.

However, Aquino's other recommendations regarding depoliticization and confidentiality merit further consideration. ${ }^{203}$ Mediator neutrality and process confidentiality are, of course, hallmarks of U.S.-style mediation. But in cases involving issues of great social concern, these features are of secondary importance. In Nicaragua, for example, a mediation committee or third-party advocacy organization committed to the eradication of domestic violence "invite[s]" or "effectively require[s]" a spouse accused of it to take part in mediation. ${ }^{204}$ As Raquel Aldana and Leticia Saucedo argue, "[t]hese

197 Aquino, supra note 66, at 19.

198 Interview with Cobbie Palm, Dir., Silliman University Justice and Peace Ctr. in Dumaguete City, Phil. (July 12, 2010) (on file with author).

199 Aquino, supra note 66, at 19.

200 Id. at $17-18$.

201 Aquino, supra note 66, at 17; see also S. Golub, Non-State Justice Systems in Bangladesh and the Philippines, manuscript prepared for U.K. Dept. of Intl. Dev. 11 (2003), available at http://www.gsdrc.org/docs/open/DS34.pdf (noting "clientelist politics and gender bias" of KP system). Aquino's recommendation is equally applicable in court-annexed mediations. In one mediation I observed, the mediator, a man, told one party-in the presence of the other, both women-that perhaps the other party is suing her because of her jealousy of her beauty. Author's observation notes of mediations at Philippine Mediation Center, Caloocan City, Philippines (July 14, 2010) (on file with author).

202 One barangay captain, who has been elected successively, I interviewed told me that she has invariably appointed her husband as chair of the Lupon. Cabrera interview, supra note 101; see also Mojares, supra note 92, at 35 (Lupon members in Cebu in 1980s predominantly middle-aged males).

203 Aquino, supra note 66, at 9.

204 Aldana \& Saucedo, supra note 3, at 1324. 
methods, along with public shaming, are outside the traditional mediation practices and yet have proven effective in establishing the credibility of mediation as a powerful dispute resolution tool."205

Franco makes a similar observation vis-à-vis the role of third-party advocacy organizations committed to land reform in the Philippines:

First, rural poor petitioners need access to a solid support structure, or alternative "rights-advocacy" network, for more effective political-legal mobilization. Second, they need an integrated political-legal strategy that was capable of simultaneously (i) activating state agrarian reform law, (ii) exploiting independent state actors' pro reform initiatives, and (iii) resisting the legal and extra-legal maneuvers of anti-reform elites. ${ }^{206}$

In these situations, neutrality and confidentiality ignore and individualize social problems that, importantly, these states have explicit policies to remedy. In the process, neutrality, confidentiality, and individuation delimit the types of justice parties can access - in Cain's parlance, to the professionalized and incorporated varieties. With respect to issues of broad social concern, therefore, genuine access to justice and self-determination requires the collectivization and politicization of disputes, that is, the articulation of substantive normative agendas. This means the involvement of third-party advocacy organizations. Here, it is incumbent upon the mediator, parties, and third-party advocacy organizations to raise the collective, political grain of individual disputes. This opening up of the KP process has its risks, of course, especially in a country with an active communist insurgency. Palm told me that his group's advocacy led to its identification with the armed left, which then allowed the barangay captain to ask for military assistance. ${ }^{207}$ Nonetheless, doing so is the only way to ensure that parties access the full range of outcomes befitting a nationalist, working class agenda.

205 Id. at 1324.

206 Franco, supra note 181, at 1869; see also MERRY \& MILNER, supra note 30, at 9 ("Unless it establishes a base of power outside the state legal system, popular justice is more likely to entrench and reinforce social changes already occurring in other segments of society or to consolidate changes accomplished through other forms of political transformation.").

${ }^{207}$ Palm interview, supra note 198. 


\section{Reforming Court-Annexed Mediation and Judicial Dispute Resolution}

The aforementioned recommendations apply equally to court-annexed mediation where litigants are coerced into mediation and judicial dispute resolution, go through a protracted process, and are then pressured to settle. ${ }^{208}$ As Timothy Hedeen has observed, self-determination may be compromised by various pressures to enter, continue, and settle in mediation. ${ }^{209}$ Courts routinely order parties to mediation, and to engage the process in "good faith." ${ }^{10}$ Parties often also defer to mediators in deciding whether or not to continue with mediation. ${ }^{211}$ And there is always, by definition, the pressure to settle. ${ }^{212}$ To promote individual self-determination in court-connected mediations, Hedeen argues that:

1) referrals to mediation... be explicitly free of coercion; 2) mediation consent forms ... be executed at the outset of mediation to affirm the disputants' informed consent ... and understanding of a) the bounds of acceptable mediator pressure, b) their rights to terminate mediation at any time, and c) the court's policy that nonsettlement will not adversely affect either party's case; 3) Welsh's "cooling-off period" between the mediation session and the date any mediated settlements are finalized should be instituted; and 4) a blanket prohibition on substantive mediator reports and recommendations to the court ... be enforced. ${ }^{213}$

Court-annexed mediation in the Philippines violates many, if not all, of these principles. To begin with, PMC mediators are paid nearly three times more if they forge settlement. ${ }^{214}$ Well aware of this fact, one mediator I observed had convened the parties ten times, and was planning on convening them even further, to settle one matter. ${ }^{215}$ In another case, I observed a

208 Interestingly, the expansion of the court-annexed mediation program contemplated by the Department of Justice would prioritize extension to areas currently fraught with armed conflict, in particular to the north and south. Malenab-Hornilla presentation, supra note 112.

209 Hedeen, supra note 135, at 275.

210 Id. at 284.

211 Id. at $279-80$.

212 Id. at $281-83$.

213 Id. at 286 (internal citations omitted).

214 See supra note 117.

215 Indeed, the form used by PMC mediators allows for that many mediations. 
woman speak to a court clerk about her good-faith engagement of the process, her reluctance to mediate further, and her request for a court hearing, only to be told by the clerk to attend yet another mediation session. ${ }^{216}$ In the Philippines, the failure to attend court-annexed mediation is harsh: dismissal or an ex parte hearing in which judgment may be rendered against the nonappearing party. ${ }^{217}$ This is, of course, coercive and violates elemental due process. Indeed, in all the court-annexed mediations I observed in the summer of 2010 , the overarching tenor was one of forbearance, the mediators invariably cajoling and pleading the parties to settle. ${ }^{218}$ As one mediator told me in pursuing a policy of scheduling at least three mediations, "We don't surrender outright. It's for their own good. They're reluctant because they're not enlightened. Once enlightened, they'll understand. Pinipiga naming ng pinipiga (we squeeze them repeatedly)." 219 These principles clearly run afoul of access to justice and self-determination standards.

Not only are people pressured into settlement, but, by law, court-annexed mediators are court officials. As one mediator told me, "we are an extension of the court." 220 The PMC, one interviewee told me, is "at the mercy of local government, it is financed by local government."221 Indeed, in one PMC office I visited, mediators sat behind their desks, as if judges, unlike the U.S. model of arraying mediators among the parties, and emphasized their status as court officers. ${ }^{222}$ This official status therefore undermines the confidentiality of the process as mediators are subject to the authority of the presiding judges. Judicial dispute resolution amounts to nothing more than yet another way to coerce settlement- this time from a judge, albeit a non-

216 Author's observation notes on Philippine Mediation Ctr. mediations in Paranaque City, Phil. (July 13, 2010) (on file with author).

${ }^{217}$ Philippine Mediation Center Frequently Asked Questions, http://www.pmc.org.ph/faq-the-case-for-mediation.htm (last visited Nov. 1, 2011 ).

218 The cajoling ranged from invoking Filipino identity ("Pinoy naman tayo") to the mediator's patience ("nagtitiis"), to warning the parties that they might "get accused in a counterclaim" or "get cited in contempt of court," to using "your vacation days if you appear in court." Caloocan PMC observation notes, supra note 201; Paranaque PMC observation notes, supra note 217.

219 Interview with Nelson Suguitan, staff, Philippine Mediation Center in Caloocan City, Philippines (July 14, 2010).

220 Id.

221 Inocencio interview, supra note 215.

222 Caloocan PMC observation notes, supra note 201; Paranaque PMC observation notes, supra note 217 . At Caloocan, one mediator told the parties to not minimize the import of the process ("huwag ninyong mamaliitin") as it is part of the court's process. 
presiding 'one. Here, the pressure to settle is obvious. As Judge $\mathrm{Fe}$ Bustamante of Dumaguete told me in an interview, "I think judges should not mediate."223

In sum, each of the three systems governing Philippine community mediation is fraught with features that undermine genuine access to justice and self-determination. Indigenous dispute resolution needs to be better known and understood. Respect, not disregard or cooptation, ought to be the governing principle governing state responses to such processes, which, where necessary, must be supplemented or collaterally reviewed to ensure due process and other fundamental human rights. The neighborhood justice system ought to be voluntary, more gender-balanced, and depoliticized from the influence of local elites. In cases involving issues of social importance, neutrality and confidentiality must give way, and mediators and concerned third-party organizations provided advocacy roles. Court-annexed mediation and judicial dispute resolution likewise must be voluntary. All the various institutional pressures to settle-higher mediator fees for cases settled, case dismissal for nonappearance, and others-must be done away with. To ensure genuine access to justice and self-determination in Philippine community mediation, what is required is no less than structural reform and counter-hegemonic resistance. Without such efforts, these processes make a mockery out of mediation's hallowed objectives.

\section{CONCLUSION-FROM INFORMAL TO SOCIAL JUSTICE}

Access to justice and self-determination by the disenfranchised and marginalized are central to the internationalization of U.S.-style ADR. Yet neocolonialist ideology pervades the propagation of U.S.-style mediation in the Philippines. These programs fail to recognize, disrespect, marginalize, assimilate, or integrate indigenous dispute resolution. They support a compulsory neighborhood justice system that is jurisdictional, patronagebased, politicized, and controlled by ruling elites often subservient to foreign interests. And they propagate a court-annexed mediation process that is skewed toward compulsory resolution and designed primarily to channel grassroots social conflict into forums that absorb political demand. As a consequence, ordinary Filipinos face enormous obstacles to access to justice and self-determination on the ground.

223 Interview with Fe Bustamante, Regional Trial Court Judge in Dumaguete, Phil. (July 12, 2010). 
Dispute-processing is a cornerstone of democratic governance, and Filipinos have a rich tradition of governing from below. From pre-conquest societies, to the revolutions against Spain and the United States, to the People Power uprisings of 1986 and 2001, we have exercised our right to govern against colonial, dictatorial, and corrupt regimes. So, too, must our choice of dispute-resolution forums and participation in them. Without reforming current ADR procedures, access to justice and self-determination are mythical goals. 
